\title{
Effect of Petroleum Fuels and Lubricants on Soil Properties of Auto-mechanic Workshops and Garages in Cape Coast Metropolis, Ghana
}

\author{
${ }^{* 1}$ NYARKO, HD; ${ }^{2}$ OKPOKWASILI, GC; ${ }^{1}$ JOEL, OF; ${ }^{3}$ GALYUON, IAK \\ ${ }^{*}$ World Bank African Centre of Excellence in Oilfield Chemicals (ACE-CEFOR), Department of Environmental Technology and \\ Management, ${ }^{2}$ Department of Microbiology, University of Port Harcourt, Port Harcourt, Nigeria. \\ ${ }^{3}$ Department of Molecular Biology and Biotechnology, University of Cape Coast, Cape Coast, Ghana. \\ *Corresponding Author Email: hnyarko@ucc.edu.gh,Tel:+233244287616 \\ OtherAuthorsEmail: gidsilman@yahoo.com; ogbonna.joel@ipsng.org; igalyuon@ucc.edu.gh
}

\begin{abstract}
Soil properties of petroleum hydrocarbon contaminated soils from automobile mechanical shops in the Cape Coast Municipality of the Central Region of Ghana were investigated to assess their alternation due to the petroleum hydrocarbon contamination. Soil samples were collected from eight automobile mechanical shops and control sites and analyzed using standard protocols. The mean particle size distribution followed the order: sand $64.79 \pm 19.47>$ silt $22.81 \pm 9.47>12.40 \pm 14.68$. The distributions for the control samples followed a similar order. The particle size distribution of soils from the study sites was not significantly different from those of the control sites $(p<0.05)$. There were greater variations in soil characteristics of control samples than those of the contaminated soils, with significant differences observed between most of the soil characteristics of the two sites $(\mathrm{p}<0.05)$. Significant correlations were observed between some soil properties, between temperature and conductivity $(\mathrm{p}<0.01 ; \mathrm{r}=-0.689)$; temperature and organic matter $(\mathrm{p}<0.05$; $\mathrm{r}=0.422) ; \mathrm{pH}$ and conductivity $(\mathrm{p}<0.01 ; \mathrm{r}=0.549) ; \mathrm{pH}$ and nitrate $(\mathrm{p}<0.05 ; \mathrm{r}=0.430) ; \mathrm{pH}$ and Phosphate $(\mathrm{p}<0.01 ; \mathrm{r}=$ $0.652)$; nitrate and phosphate $(\mathrm{r}=0.728, \mathrm{p}<0.01)$, organic matter and phosphate $(\mathrm{p}<0.01 ; \mathrm{r}=0.692)$; moisture and nitrate $(r=0.787, p<0.0)$; and between moisture and phosphate $(r=0.633, p<0.01)$. Petroleum hydrocarbon contamination altered soil properties and may adversely affect sensitive bacteria.
\end{abstract}

DOI: https://dx.doi.org/10.4314/jasem.v23i7.15

Copyright: Copyright (C) 2019 Nyarko et al. This is an open access article distributed under the Creative Commons Attribution License (CCL), which permits unrestricted use, distribution, and reproduction in any medium, provided the original work is properly cited.

Dates: Received: 26 May 2019; Revised: 19 June 2019; Accepted 10 July 2019

Keywords: Physiochemical properties, Soil, Petroleum hydrocarbon, Contamination

The transforming crude oil into petrochemicals, including gasoline and lubricating oil for use by automobiles, has led to worldwide contamination of air, water and soils are dangerous for human and ecosystem health (Ahmad et al., 2016; Patil et al., 2004; WHO, 2014). Soil plays a vital role in maintaining the balance of the earth's ecosystem (Nesme et al., 2014), but contamination by petroleum products is a current problem in several countries in the world. The deleterious effects of these petroleum products on the soil ecosystem are due to toxic components (Ujowundu et al., 2011). The detrimental effects of auto-mechanic workshop activities on humans and soils, as well as arable lands, have been reported in Nigeria (Nkwoada et al., 2018; Oluwajiose et al., 2015; Demie, 2015).

The petroleum fuels are composed of saturated hydrocarbon, aromatic hydrocarbon and nonhydrocarbon compounds (Lin et al., 2010), and traces of nitrogen, phosphorus and organic matter, which are easily absorbed in the soil surface (Wang et al., 2009). Studies have revealed that hydrocarbon with benzene ring are quite complex, insoluble in water and are not easily removed from the soil due to low boiling of the hydrocarbons (Guo et al., 2016; Bayat, 2015). The petroleum hydrocarbon affects the soils hydrophobicity and moisture holding capacity (Balks et al., 2002); permeability and porosity of soils (Wang, et al., 2009; He et al, 1999); fungal and bacterial growths, and have higher metal enrichment (Zhang et al., 2018; Shamiyan et al., 2013); soil physicochemical properties (Wan, 2014; Ezeigbo et al., 2013; Nwaogu and Onyeze, 2010), and eventually damage the soil environment (Dindar et al., 2015). The bulk density, porosity, and nutrient levels: nitrogen, carbon and phosphorus absorption of crops in hydrocarbon contaminated soils have been affected (Liao et al, 2015; Kumar \& Rao, 2012). Most auto-mechanic workshops and garages in developing countries do not have regulatory codes for their operations, especially the disposal of their used oil and other wastes (Kpakpavi, 2015). The soils in these operational sites are major repositories of different wastes and pollutants generated from activities of these shops, 
hence the natural soils in mechanical garages are mainly contaminated with residual polycyclic aromatic hydrocarbons and non-hydrocarbons. Garage and auto-mechanical workshops are also a source of a hazardous pollutant for soil resource, causing deterioration of quality of soil and disruption of normal function of soil resources. Most of the investigations carried out at some of these sites focused on the heavy metal pollution of soils from spilled oils and other contaminants. The provision of any code of practice to regulate the activities of these workshops and motor vehicle service industries to achieve the general environmental duty of maintaining soil quality would have to be based on scientific data. In Ghana, however, there is no data on the effects of hydrocarbon contamination of these workshops and garages on the soil properties, and their overall impact on the quality of the soils. The aim of this present study was to determine physicochemical properties and soil organic matter contents of petroleum hydrocarbon contaminated soils from vehicular mechanical workshops in the Cape Coast Metropolis of the Central Region of Ghana and to assess the effect of the contamination on the soil characteristics and environment. A better understanding of the effects of petroleum hydrocarbon contamination on soil physicochemical properties and bacterial community has potential contributions to the improvement of crop productivity, degradation and remediation of oil polluted soil. Vehicular mechanical workshop sites were selected for study since oil, both used and unused are often spilled, accidentally or deliberately into soils in these operational sites, and are relatively much contaminated with petroleum hydrocarbons than soil in other areas. Also, the urban nature of the Cape Coast Metropolis with the numerous automobile servicing shops within the small city makes it suitable as a study area.

\section{MATERIAL AND METHODS}

Description of study area: Cape Coast, the study area is a fishing city in the Central region of Ghana. It is situated on its south to the Gulf of Guinea and $120 \mathrm{~km}$ southwest of the capital of Ghana, Accra (Fig. 1). The city had a total settlement population of 169,894 people (GSS, 2010 census). The sites investigated were automobile mechanic workshops at Pedu, Kakumdo, Greenhill, Brafoyaw, and Siwdu. Pristine (unpolluted) soils, which represented the control samples were collected between 50-100 metres away from each polluted site. A global positioning system (GPS) used to determine the coordinates of the sampling locations, ranged from longitude $1^{\circ} 13^{\prime} 7^{\prime}$ W

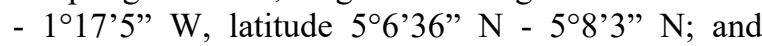
altitude $1.544861-53.28717$.
Sample collection and preparation: A total of fourteen composite soil samples from eight petroleum hydrocarbon-contaminated sites and six pristine (control) sites, were investigated. Three replicate soil samples were randomly collected from each sampling station using a soil auger at depth $(0-15 \mathrm{~cm})$ to form the composite sample.

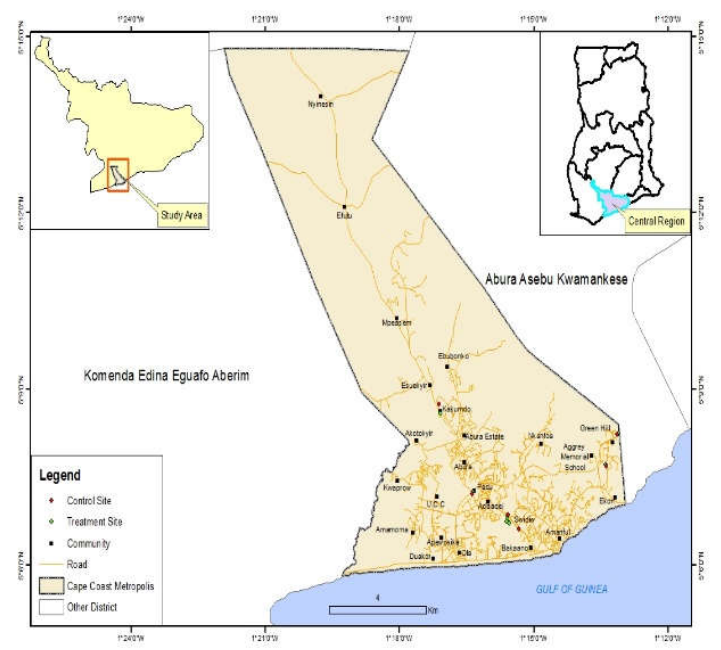

Fig 1: Map of study area showing sampling locations in the Cape Coast Metropolis, Ghana

The soil samples were quickly put into sterile, ziplocked polyethylene plastic bags, labelled and subsequently transported to the laboratories in the iced chest for physicochemical analyses. Soil samples were air dried for 72 hours at room temperature, and then ground and sieved with a $2.0 \mathrm{~mm}$ mesh.

Soil Analyses: Soil properties namely; temperature, $\mathrm{pH}$, electrical conductivity, nitrate content, phosphate content, moisture content, bulk density, porosity, particle size distribution, texture, as well as total organic matter content were analyzed using standards protocols in laboratories of the School of Physical of Sciences, University of Cape Coast, Ghana.

Temperatures of soil samples at designated locations in the field were measured by inserting mercury in bulb thermometer to a depth of $5 \mathrm{~cm}$ in the soil. Electrical conductivity and $\mathrm{pH}$ of soils were measured following aqueous soil suspension method (ISO 10390:2005) as described by Useh et al., (2015). A soil: water mixture of 1:5 (w/v) was prepared using 10 $\mathrm{g}$ air-dried soil sample in $50 \mathrm{ml}$ deionized water and allowed to stand for 10 minutes. The electrode of the digital multi-meter (Hanna model) was immersed in the mixture for each determination. Nitrate and phosphate levels in test soil samples were respectively determined by spectrophotometric methods 8171 and 8048, using the portable DR 900 multi-parameter 
spectrophotometer. For total organic carbon determinations, the loss on ignition method (DIN 19684-3 2000-08) described by Wilke (2005) was employed. The direct method using dry mass on a mass basis (ISO 11465: 1993) and core method (ISO DIS 11272:2017), both described by Wilke (2005) were employed for soil moisture content and bulk density determinations, respectfully. The porosity, which represents the total amount of pore spaces present in soil inorganic separates was expressed in percent by the formula:

Porosity $(\%)=\left(1-\frac{D_{b}}{D_{d}}\right) \times 100 \quad \ldots 1$

Where; $D_{b}$ is the bulk density of soil sample; $D_{d}$ is the particle density of soil sample

Each composite soil sample was analyzed for the relative proportions of mineral soil separates namely; sand, silt, and clay using the sieve analysis method of ASTM D6913/D6913M-17, with slight modification. Selected sieve sizes for sand, silt, and clay with diameter ranges of $0.05-2.0 \mathrm{~mm}, 0.002-0.05 \mathrm{~mm}<$ $0.002 \mathrm{~mm}$, respectfully were used in the analysis. The sieves were tightly packed such that the one with the largest openings was at the top and the smallest at the base and $500 \mathrm{~g}$ of oven-dried soil sample were poured into the top sieve and covered. The stacked sieves with the oven-dried soil were strongly agitated in a mechanical shaker for about 15 minutes. Each sieve was removed separately and the soil portions (sand, silt, and clay) retained were weighed and expressed in percentage of the total weight of the initial soil sample used. The textural classes were determined using the USDA textural triangle.

\section{RESULTS AND DISCUSSION}

The descriptive statistics of the particle size distribution (Table 1) show that hydrocarbon polluted soils were characterized by relatively high sand content ranging from $25.0-83.0 \%$, and an average $($ mean \pm sd) of $64.79 \pm 19.47 \%$; silt $5.9-34.6 \%$ $(22.81 \pm 9.47 \%)$ and clay $2.5-47 \%(12.04 \pm 14.68 \%)$. The ranges and mean of particle size distribution for the control samples were: sand 3.0-74.4\% $(42.72 \pm 25.39 \%)$; silt $14.3-94.0 \% \quad(47.47 \pm 30.85 \%)$; and clay $3.0-23.8 \%(9.82 \pm 7.63 \%)$. The textural designations of soils from the study sites were mostly sandy loam. Soil samples from SS 1 - SS4 were of varying texture; sandy loam, loamy sand, and clay. With the exception of test and control samples from KS and KSC that showed the same textural designation (sandy loam), the remaining soils, both test, and their controls samples showed different textural classes.

Table 1: Mean particle size distribution and textural designations of soils

\begin{tabular}{|c|c|c|c|c|c|c|c|c|c|}
\hline \multirow{2}{*}{$\begin{array}{l}\text { Sample } \\
\text { location }\end{array}$} & \multicolumn{3}{|c|}{ Test Sample } & \multirow{2}{*}{$\begin{array}{l}\text { Textural } \\
\text { class }\end{array}$} & \multirow{2}{*}{$\begin{array}{l}\text { Sample } \\
\text { location }\end{array}$} & \multicolumn{3}{|c|}{ Control Samples } & \multirow{2}{*}{$\begin{array}{l}\text { Textural } \\
\text { class }\end{array}$} \\
\hline & Sand \% & Silt \% & Clay \% & & & Sand $\%$ & Silt \% & Clay \% & \\
\hline BYS & 83.0 & 14.5 & 2.5 & Loamy sand & BYSC & 3.0 & 94.0 & 3.0 & Silt \\
\hline GS & 61.8 & 36.6 & 3.6 & Sandy loam & GSC & 35.1 & 57.8 & 7.1 & Loam \\
\hline KS & 55.4 & 32.1 & 12.5 & Sandy loam & $\mathrm{KSC}$ & 74.4 & 16.7 & 8.9 & Sandy loam \\
\hline PJS & 70.3 & 24.3 & 5.4 & Sandy loam & PJSC & 51.2 & 36.6 & 12.2 & Loam \\
\hline SS 1 & 62.5 & 25.0 & 12.5 & Sandy loam & SSC I & 30.7 & 65.4 & 3.9 & Silt loam \\
\hline SS 2 & 82.5 & 5.9 & 5.9 & Loamy sand & SSC II & 61.9 & 14.3 & 23.8 & Sandy loam \\
\hline SS 3 & 25.0 & 27.5 & 47.5 & Clay & - & - & - & - & - \\
\hline SS 4 & 72.1 & 18.6 & 9.3 & Sandy loam & - & - & - & - & - \\
\hline $\begin{array}{l}\text { Mean } \pm \\
\text { sd }\end{array}$ & $\begin{array}{l}66.79 \pm \\
19.47\end{array}$ & $\begin{array}{l}22.81 \\
\pm 9.47\end{array}$ & $\begin{array}{l}12.40 \pm \\
14.68\end{array}$ & & $\begin{array}{l}\text { Mean } \pm \\
\text { sd }\end{array}$ & $\begin{array}{l}42.72 \pm \\
25.39\end{array}$ & $\begin{array}{l}47.47 \pm \\
30.85\end{array}$ & $\begin{array}{l}9.82 \pm \\
7.63\end{array}$ & \\
\hline
\end{tabular}

The descriptive statistics results of the physicochemical characteristics of petroleum hydrocarbon contaminated soils sampled from mechanical vehicular servicing shops are shown in Table 2 - 4. The mean temperatures for the study sites range between $28.00{ }^{\circ} \mathrm{C}-35.67{ }^{\circ} \mathrm{C}$, with an overall mean of $32.04 \pm 3.13{ }^{\circ} \mathrm{C}$ (Table 2). Generally, the temperatures of soils from the hydrocarbon contaminated sites were not significantly different from those of the control sites. However, Wang et al., (2013) observed significantly lower soil temperature than those at the control sites. The temperature has been observed to affect the bacteria consortium and its efficacy in biodegradation (Walker et al., 1976). The $\mathrm{pH}$ of test soils investigated was slightly acidic to slightly basic, with a mean $7.62 \pm 0.48$. Soils from BYS had the lowest mean $\mathrm{pH} 6.76$ and soils from SS 1 had the highest of 8.24 (Table 2). Only three sites (GS, BYS and SS 2) had soil $\mathrm{pH}$ values that corroborated with soil series of Ghana (Yawson et al., 2011), which ranged from 3.7 - 7.8. The $\mathrm{pH}$ of soils in the study area was slightly lower than the levels reported in the Niger Delta region of Nigeria (Udeh et al., 2013). Contrary to the earlier comparison, $\mathrm{pH}$ levels of the study areas 
were found to be higher than some hydrocarbon contaminated soils in Nigeria. At Eluama, in Abia State, pH was 4.5 (Ezeigbo et al., 2013); and 6.5, at Bomuin, in Ogoni land of Gokana local government area of Rivers State (Stanley et al., 2017). The $\mathrm{pH}$ levels of soil samples were similar to those from some uncontaminated sites in Momoge Wetland of China (Wang et al., 2013). Previous studies have reported that increased in total petroleum hydrocarbon can lower the soil pH (Leahy and Colwell, 1990; Gong et al., 2008; Kisic et al., 2009). It is also reported that oil pollution of soil raised soil pH (Jia et al., 2009); and that the hydrocarbons concentrations in the soils sampled had no significant effect on the soil $\mathrm{pH}$. The $\mathrm{pH}$ may have some effect on the diversity of soil bacteria as having been reported that, North and South American soils revealed that phosphate and $\mathrm{pH}$ affected bacterial diversity (Faoro et al., 2010). The acidity of the soils also suggests that accumulation of metals by cation exchange will be minimal and metal accumulation will predominantly be due to adsorption via soil organic matter.

The soil from GS had the least conductivity, 77.22 $\mu \mathrm{S} / \mathrm{cm}$ as against soil samples from SS 4 that showed the highest conductivity of $407.63 \mu \mathrm{S} / \mathrm{cm}$. The conductivity of soil from the control sites was lower and ranged from $46.39-256.63 \mu \mathrm{S} / \mathrm{cm}$ (Table 2).

The soils from the study sites were characterized by relatively low water content, which ranged between $0.71 \pm 0.61$ and $2.85 \pm 0.31 \%$ (Table. 3 ). The moisture content of soils at the control sites was between $0.84 \pm 0.15$ and $10.20 \pm 3.68$. Soils from the control sites generally had higher water content than those at the hydrocarbon contaminated sites except that at BYS. This observation agrees with findings elsewhere (Wang et al., 2013). The petroleum hydrocarbon coats the soil surface and reduces water permeability by blocking the soil pores resulting in the low moisture contents of the soils (Bennett et al., 1993; Roy et al., 1999; Khamehchiyan et al., 2007). The porosity of the study sites ranged between $20.86 \pm 3.17$ and $31.79 \pm 6.56 \%$ (Table 3 ). These were much lower than levels observed for the control sites, which was between $24.77 \pm 8.96$ - $41.86 \pm 6.28 \%$. The lower porosity of the oil-contaminated soils from the study sites suggests that the petroleum hydrocarbon oil in the soils have compacted the soil particles together, thereby decreasing porosity, and compromises the quality of soil structure. Porosity determines the depth to which air and water penetrate the soil (Ndimele et al., 2018; Nimmo, 2004). Soil compaction is an important environmental problem and it causes physical degradation by adversely influencing hydraulic properties of soil and productivity parameters. It can affect root development and nutrient uptake (Parlak and Parlak, 2011). The bulk density of soils from the study sites (Table 3), ranged from $1.81 \pm 0.17-2.09 \pm 0.08 \mathrm{~g} / \mathrm{cm}^{3}$, and higher than those of the control sites $1.54 \pm 0.16-1.99 \pm 0.23 \mathrm{~g} / \mathrm{cm}^{3}$. With the exception of the sample from GS that had lower bulk density, $1.95 \pm 0.10 \mathrm{~g} / \mathrm{cm} 3$, than the control sample $1.99 \pm 0.23 \mathrm{~g} / \mathrm{cm}^{3}$, the remaining sites had relatively higher bulk densities. The decreased porosity observed for the soils reflects the increased in bulk density. Thus, this limits root penetration; air and water permeability is decreased and is likely to impact on microbial survival (Pathak et al., 2011). It is reported that soil microbes acquire organic carbon and nitrogen from organic matter, and this nutrient affects the microbial community (Schnecker et al., 2014). Soils from SS 3 had the lowest organic carbon, $10.43 \pm 0.21 \%$ whilst samples from BYS showed the organic carbon content of $25.98 \pm 7.14 \%$ (Table 4 ). The control samples had lower carbon contents between 2.55 and $21.95 \%$, except for soils samples from SS3 and SS4. The organic carbon for both the contaminated and the control soils samples respectively, $25.98 \pm 7.14$ and $21.95 \pm 5.18$ was highest for samples from BYS. The higher organic carbon contents of the soils from the automobile mechanical shops could be attributed to contribution from petroleum hydrocarbon in the petroleum products as observed elsewhere (Abosede, 2013). The increase in the soil carbon content of the contaminated sites is likely to adversely affect the rate of degradation by microbes. The results of nutrient contents (phosphates, nitrates, and carbons) of contaminated soil samples and their control counterparts are presented in Table 4. The nitrate concentration ranged between $7.93 \pm 1.67$ and $17.10 \pm 2.51 \mathrm{mg} / \mathrm{L}$. The soil sample from SS 3 contained the least nitrate, and sample from BYS had the highest nitrate concentration. The mean nitrate for all the sites was $15.09 \pm 9.01 \mathrm{mg} / \mathrm{L}$. The mean for the control samples was $14.31 \pm 8.93 \mathrm{mg} / \mathrm{L}$, and range between $4.76 \pm 0.15$ and $30.30 \pm 2.38 \mathrm{mg} / \mathrm{L}$. The phosphate contents of the soils ranged between $5.73 \pm 0.90 \mathrm{mg} / \mathrm{L}$ and $28.59 \pm 1.58 \mathrm{mg} / \mathrm{L}$. Soil from BYS had the least soil phosphates, and SS 3, the highest. The mean value for all the sites was $16.53 \pm 6.28 \mathrm{mg} / \mathrm{L}$. The mean and range for the control samples were respectively $8.21 \pm 7.48 \mathrm{mg} / \mathrm{L}$ and $3.0 .74 \pm 0.32$ $20.69 \pm 2.58$. Generally, the phosphates and nitrate levels of soils from the automobile mechanical shops were higher than those of the control sites, suggesting that there had been phosphates and nitrate addition from the petroleum products. Crude oil and its product have been observed to contain nitrogen and phosphate, which affect the soil nutrient and bacteria diversity, and that the increase in soil phosphate could affect the soil bacteria diversity (Faoro et al., 2010). Carbon and nitrogen are vital for the survival of soil 
microorganisms. This finding implies that the carbon: nitrogen ratio of soils in the study sites are likely to be altered by petroleum hydrocarbon contamination, and could affect the capacity of soil bacteria to decompose materials and their decomposition rate (Pathak et al., 2011).

Table 2: Descriptive statistics of some physicochemical characteristics of petroleum hydrocarbon-polluted and pristine soils from selected automobile workshops in the Cape Coast Metropolis

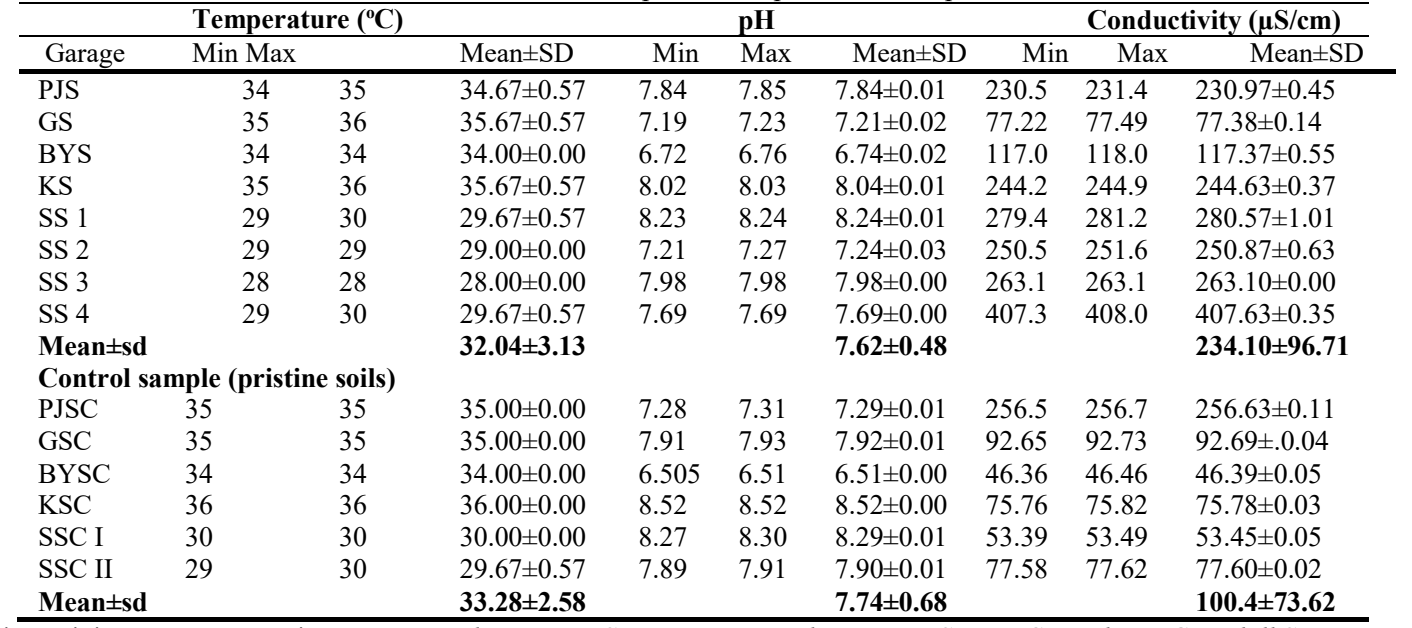

Min= Minimum; Max= Maximum ; PJS-Pedu Junction Station, PJSC- Pedu Junction Station Control, GS-Greenhill Station, GSCGreenhill Station Control, BYS-Brafoyaw Station, BYSC-Brafoyaw Station Control, KKS-Kakumdo Station, KKSC-Kakumdo Station Control, SS 1-Swidu Station 1, SS 2-Swidu Station 2, SS 3-Swidu Station 3, SS 4-Swidu Station 4, SSC I - Swidu Station Control I, SSC IISwidu Station Control I

Table 3: Descriptive statistics of some physicochemical characteristics of petroleum hydrocarbon-polluted and pristine soils from selected automobile workshops in the Cape Coast Metropolis

\begin{tabular}{|c|c|c|c|c|c|c|c|c|c|}
\hline & \multicolumn{3}{|c|}{ Moisture Content (\%) } & \multicolumn{2}{|c|}{ Porosity (\%) } & \multicolumn{4}{|c|}{ Bulk Density } \\
\hline & Min & Max & Mean \pm SD & Min & Max & Mean \pm SD & Min & Max & Mean \pm SD \\
\hline PJS & 0.90 & 0.91 & $0.91 \pm 0.00$ & 17.2 & 22.85 & $20.86 \pm 3.17$ & 2.0446 & 2.1942 & $2.09 \pm 0.08$ \\
\hline GS & 1.11 & 1.32 & $1.21 \pm 0.10$ & 22.37 & 30.24 & $26.44 \pm 3.94$ & 1.8488 & 2.0571 & $1.95 \pm 0.10$ \\
\hline BYS & 0.88 & 1.01 & $0.96 \pm 0.07$ & 25.56 & 38.64 & $31.79 \pm 6.56$ & 1.6261 & 1.9728 & $1.81 \pm 0.17$ \\
\hline KS & 1.52 & 2.56 & $2.22 \pm 0.60$ & 19.97 & 37.52 & $28.62 \pm 8.77$ & 1.6558 & 2.1209 & $1.89 \pm 0.23$ \\
\hline SS 1 & 1.11 & 1.32 & $1.21 \pm 0.10$ & 14.1 & 30.61 & $21.71 \pm 8.33$ & 1.8382 & 2.2763 & $2.07 \pm 0.22$ \\
\hline SS2 & 1.31 & 1.73 & $1.52 \pm 0.20$ & 13.63 & 35.52 & $23.93 \pm 11.00$ & 1.7085 & 2.2887 & $2.01 \pm 0.29$ \\
\hline SS3 & 2.67 & 3.21 & $2.85 \pm 0.31$ & 18.87 & 28.2 & $24.38 \pm 4.88$ & 1.9027 & 2.1500 & $2.00 \pm 0.13$ \\
\hline SS 4 & 0.01 & 1.11 & $0.71 \pm 0.61$ & 11.31 & 32.6 & $24.60 \pm 11.58$ & 1.7861 & 2.3503 & $1.99 \pm 0.31$ \\
\hline $\operatorname{Mean} \pm \mathbf{s d}$ & & & $1.45 \pm 0.75$ & & & $25.29 \pm 7.40$ & & & $1.98 \pm 0.19$ \\
\hline \multicolumn{10}{|c|}{ Control sample (pristine soils) } \\
\hline PJSC & 3.30 & 4.40 & $3.80 \pm 0.53$ & 37.87 & 49.11 & $41.86 \pm 6.28$ & 1.3486 & 1.6465 & $1.54 \pm 0.16$ \\
\hline GSC & 5.59 & 7.76 & $6.57 \pm 1.09$ & 14.42 & 30.56 & $24.77 \pm 8.96$ & 1.8401 & 2.2679 & $1.99 \pm 0.23$ \\
\hline BYSC & 2.56 & 2.77 & $2.70 \pm 0.12$ & 31.17 & 44.65 & $36.37 \pm 7.24$ & 1.4667 & 1.7676 & $1.62 \pm 0.15$ \\
\hline $\mathrm{KSC}$ & 1.31 & 1.63 & $1.45 \pm 0.15$ & 22.31 & 33.64 & $27.41 \pm 5.74$ & 1.7585 & 2.0587 & $1.92 \pm 0.15$ \\
\hline SSCI & 0.71 & 1.01 & $0.84 \pm 0.15$ & 16.33 & 32.26 & $25.08 \pm 8.08$ & 1.7952 & 2.2173 & $1.98 \pm 0.21$ \\
\hline SSC II & 5.94 & 12.43 & $10.20 \pm 3.68$ & 32.05 & 34.84 & $33.46 \pm 1.39$ & 1.7268 & 1.7623 & $1.74 \pm 0.01$ \\
\hline $\operatorname{Mean} \pm$ sd & & & $4.26 \pm 3.59$ & & & $31.49 \pm 8.61$ & & & $1.80 \pm 0.23$ \\
\hline
\end{tabular}

Min=minimum, Max=maximum, PJS-Pedu Junction Station, PJSC- Pedu Junction Station Control, GS-Greenhill Station, GSC- Greenhill Station Control, BYS-Brafoyaw Station, BYSC-Brafoyaw Station Control, KKS-Kakumdo Station, KKSC-Kakumdo Station Control, SS 1Swidu Station 1, SS 2-Swidu Station 2, SS 3-Swidu Station 3, SS 4-Swidu Station 4, SSC I - Swidu Station Control I, SSC II-Swidu Station Control II.

The strength of relations amongst the physicochemical parameters of the soils collected from the selected automobile workshops was assessed using regression analysis and Spearman's Correlations (Table 5). Temperature showed significant, moderately negative correlation with conductivity $(\mathrm{p}<0.01 ; \mathrm{r}=-0.689)$ and correlated positively with organic carbon $(\mathrm{p}<0.05 ; \mathrm{r}=$ 0.422). A significant positive correlations were observed between $\mathrm{pH}$ and conductivity $(\mathrm{p}<0.01 ; \mathrm{r}=$
$0.549) ; \mathrm{pH}$ and Phosphate $(\mathrm{p}<0.01 ; \mathrm{r}=0.652)$; and with nitrate $(\mathrm{p}<0.05 ; \mathrm{r}=0.430)$. The moisture content correlated positively and significantly with nitrate and phosphate at the $\mathrm{p}<0.0$, with coefficients respectively $\mathrm{r}=0.787$ and $\mathrm{r}=0.633$. The stronger coefficient for nitrate suggests a greater bio-availability of nitrate than phosphate. The nitrate concentrations of soils at the control and study sites were generally higher than corresponding phosphate levels (Table 6), similar to 
observations made elsewhere in Lybia (Mussa et al., 2009). The availability of these nutrients is also dependent on the soil $\mathrm{pH}$ as have been reported (Alzoubi and Gaibore, 2012). Excessive phosphate at SS locations, in particular, may result in water pollution due to runoff. The significantly stronger positive correlation between the soil nitrate and phosphate $(\mathrm{p}<0.01 ; \mathrm{r}=0.728)$, imply that these nutrient were from some common source, most probably the petroleum hydrocarbons in the contaminated soils. A positive correlation was also observed between the soil organic carbon nitrate and phosphate $(\mathrm{p}<0.01 ; \mathrm{r}=0.692)$. This suggests soil organic matter as a probable source of the phosphate. The coefficient of determination, calculated by multiplying the square of the correlation coefficient by $100 \%$, and which expresses the contribution of the organic matter/carbon to the variation in soil phosphate was found to be $47.89 \%$. Thus, about $48.89 \%$ of the soil phosphate is the soil organic matter. No significant correlation was observed between the soil carbon and nitrate. Carbon and nitrogen are two chemical elements in organic matter that are, extremely important especially in their relation or proportion to each other. The non-significant correlation observed may thus imply alternation of the $\mathrm{C} / \mathrm{N}$ ratio, which may adversely affect some soil microorganism as reported (Marais et al., 1998; Smit et al., 2001; Youssef and Elshahed, 2008)

Table 4: Descriptive statistics of some physicochemical characteristics of petroleum hydrocarbon-polluted and pristine soils from selected automobile workshops in the Cape Coast Metropolis

\begin{tabular}{lllllllllll}
\hline & \multicolumn{3}{c}{ Nitrates $(\mathbf{m g} / \mathbf{L})$} & \multicolumn{3}{c}{ Phosphates $\mathbf{( m g} / \mathbf{L})$} & \multicolumn{3}{c}{ Organic Carbon (\%) } \\
\hline Soils & Min & Max & Mean \pm SD & Min & Max & Mean \pm SD & \multicolumn{1}{c}{ Min } & Max & Mean \pm SD \\
\hline PJS & 9.80 & 14.30 & $12.10 \pm 2.25$ & 16.74 & 24.29 & $19.47 \pm 4.18$ & 11.13 & 14.40 & $12.28 \pm 1.83$ \\
GS & 11.30 & 12.70 & $12.06 \pm 0.71$ & 6.01 & 7.10 & $6.59 \pm 0.55$ & 16.95 & 26.91 & $20.59 \pm 5.48$ \\
BYS & 6.00 & 9.00 & $7.93 \pm 1.67$ & 4.69 & 6.32 & $5.73 \pm 0.90$ & 18.58 & 32.84 & $25.98 \pm 7.14$ \\
KKS & 14.90 & 15.58 & $15.32 \pm 0.37$ & 27.92 & 28.41 & $28.19 \pm 0.24$ & 13.29 & 13.60 & $13.42 \pm 0.16$ \\
SS1 & 13.40 & 13.60 & $13.50 \pm 0.10$ & 10.87 & 11.80 & $11.48 \pm 0.53$ & 20.06 & 26.52 & $23.26 \pm 3.23$ \\
SS 2 & 16.40 & 17.60 & $16.96 \pm 0.60$ & 12.51 & 14.02 & $13.11 \pm 0.80$ & 13.29 & 13.60 & $13.42 \pm 0.16$ \\
SS 3 & 14.20 & 18.60 & $17.10 \pm 2.51$ & 26.84 & 29.94 & $28.59 \pm 1.58$ & 10.27 & 10.67 & $10.43 \pm 0.21$ \\
SS4 & 8.50 & 9.90 & $9.13 \pm 0.71$ & 6.81 & 8.81 & $7.50 \pm 1.13$ & 12.22 & 13.56 & $12.87 \pm 0.67$ \\
Mean \pm sd & & & $\mathbf{1 3 . 0 2} \pm \mathbf{3 . 4 4}$ & & & $\mathbf{1 5 . 0 9} \pm \mathbf{9 . 0 1}$ & & & $\mathbf{1 6 . 5 3} \pm \mathbf{6 . 2 8}$ \\
Control sample (pristine soils) & & & & & & & \\
PJSC & 4.60 & 4.90 & $4.76 \pm 0.15$ & 3.10 & 3.20 & $3.17 \pm 0.06$ & 5.26 & 5.59 & $5.39 \pm 0.17$ \\
GSC & 8.30 & 8.90 & $8.56 \pm 0.30$ & 9.74 & 15.09 & $12.59 \pm 2.69$ & 3.59 & 3.77 & $3.65 \pm 0.09$ \\
BYSC & 7.20 & 7.80 & $7.46 \pm 0.30$ & 1.18 & 1.82 & $1.44 \pm 0.34$ & 18.68 & 27.93 & $21.95 \pm 5.18$ \\
KKSC & 15.30 & 16.80 & $16.13 \pm 0.76$ & 17.71 & 22.25 & $20.69 \pm 2.58$ & 2.38 & 2.73 & $2.55 \pm 0.17$ \\
SSC I & 28.50 & 33.00 & $30.30 \pm 2.38$ & 9.99 & 11.24 & $10.64 \pm 0.62$ & 14.43 & 21.97 & $18.97 \pm 4.00$ \\
SSC II & 18.10 & 18.90 & $18.60 \pm 0.43$ & 0.48 & 1.11 & $0.74 \pm 0.32$ & 11.76 & 22.22 & $17.41 \pm 5.28$ \\
Mean \pm sd & & & $\mathbf{1 4 . 3 1} \pm \mathbf{8 . 9 3}$ & & & $\mathbf{8 . 2 1} \pm 7.48$ & & & $\mathbf{1 1 . 6 6} \pm \mathbf{8 . 6 7}$ \\
\hline
\end{tabular}

Min=minimum, Max=maximum; PJS-Pedu Junction Station, PJSC- Pedu Junction Station Control, GS-Greenhill Station, GSC-Greenhill Station Control, BYS-Brafoyaw Station, BYSC-Brafoyaw Station Control, KKS-Kakumdo Station, KKSC-Kakumdo Station Control, SSSwidu Station

Table 5: Spearman's Correlations of Physicochemical parameters from soils collect from selected automobile workshops in Cape Coast

\begin{tabular}{|c|c|c|c|c|c|c|c|c|c|}
\hline & Temp & $\mathrm{pH}$ & Cond & Nitrate & Phosphate & Moisture & $\mathrm{OCC}$ & $\mathrm{BD}$ & Porosity \\
\hline Temperature & 1.000 & -0.14 & $-.689 * *$ & -0.316 & -0.186 & -0.288 & $.422 *$ & -0.08 & 0.08 \\
\hline $\mathrm{pH}$ & 1.000 & & $.549 * *$ & $.430^{*}$ & $.652 * *$ & 0.373 & -0.282 & 0.227 & -0.227 \\
\hline Conductivity & & & 1.000 & 0.186 & 0.256 & 0.18 & -0.382 & 0.154 & -0.154 \\
\hline Nitrate & & & & 1.000 & $.728 * *$ & $.787 * *$ & -0.355 & 0.04 & -0.04 \\
\hline Phosphate & & & & & 1.000 & $.633^{* *}$ & $.692 * *$ & 0.252 & -0.252 \\
\hline Moisture & & & & & & 1.000 & -0.336 & 0.013 & -0.013 \\
\hline OCC & & & & & & & 1.000 & 0.312 & 0.312 \\
\hline Bulk density & & & & & & & & 1.000 & $1.000 * *$ \\
\hline Porosity & & & & & & & & & 1.000 \\
\hline
\end{tabular}

There were variations in the distributions of the soil characteristics from the control sites and the various sites contaminated with petroleum hydrocarbon. The extent of variability as revealed by the coefficient of variation $(\mathrm{CV})$ in Table 6 showed that for the particle size, clay content showed the greatest variation of $118.38 \%$ followed by silt, $88.61 \%$ and sand, $30.04 \%$. The order observed for the control samples was clay,
$77.69 \%>$ sand, $59.43 \%$. > silt $54.19 \%$. The variability of the other soil characteristics ranged from $59.71 \%$ for phosphate to $6.29 \%$ for $\mathrm{pH}$. For the control samples, the phosphate showed the greatest variation of $91.11 \%$ and temperature the least $(7.75 \%)$. The variation in the $\mathrm{pH}$ distribution was $8.79 \%$. Generally, the variability in soil physicochemical properties of the control samples was higher than those from the 
automobile shops. This may be due to the effect of petroleum hydrocarbon contamination. Multivariate comparison of the soil properties for significant differences showed that the $\mathrm{pH}$, temperature, nitrate and particle distribution of soils from the study sites were not significantly different from those of the control sites $(\mathrm{p}<0.05)$ (Table 6).

Table 6: Comparative assessment of physicochemical parameters among Hydrocarbon ontaminated soils and their controls.

\begin{tabular}{llllll}
\hline Parameter(s) & Treatment & CV & Control & CV & p-ralue \\
\hline Temperature ( $(\mathrm{C})$ & $32.04 \pm 3.13$ & 9.76 & $33.28 \pm 2.58$ & 7.75 & 0.1806 \\
pH & $7.62 \pm 0.48$ & 6.29 & $7.74 \pm 0.68$ & 8.79 & 0.5206 \\
Conductivity $(\mu \mathrm{S} / \mathrm{cm})$ & $234.10 \pm 96.71$ & 41.31 & $100.4 \pm 73.62$ & 73.33 & $<0.0001$ \\
Nitrate $(\mathrm{mg} / \mathrm{L})$ & $13.02 \pm 3.44$ & 26.42 & $14.31 \pm 8.93$ & 62.40 & 0.5209 \\
Phosphate $(\mathrm{mg} / \mathrm{L})$ & $15.09 \pm 9.01$ & 59.71 & $8.21 \pm 7.48$ & 91.11 & 0.0123 \\
Moisture $(\%)$ & $1.45 \pm 0.75$ & 51.72 & $4.26 \pm 3.59$ & 84.27 & 0.0006 \\
Soil Organic matter $(\%)$ & $16.53 \pm 6.28$ & 37.99 & $11.66 \pm 8.67$ & 74.36 & 0.0406 \\
Bulk density $\left(\mathrm{g} / \mathrm{cm}^{3}\right)$ & $1.98 \pm 0.19$ & 9.59 & $1.80 \pm 0.23$ & 12.78. & 0.0102 \\
Porosity $(\%)$ & $25.29 \pm 7.40$ & 29.26 & $31.49 \pm 8.61$ & 27.34 & 0.0164 \\
TPH (mg $/ \mathrm{kg})$ & $62674 \pm 15462$ & 24.67 & $0.00 \pm 0.00$ & 0.00 & $<0.0001$ \\
Particle size distribution & & & & & \\
\% Sand & $64.79 \pm 19.47$ & 30.04 & $42.72 \pm 25.39$ & 59.43 & 0.0894 \\
$\%$ Silt & $22.81 \pm 9.47$ & 88.61 & $47.47 \pm 30.85$ & 54.19 & 0.7294 \\
$\%$ clay & $12.40 \pm 14.68$ & 118.38 & $9.82 \pm 7.63$ & 77.69 & 0.7029 \\
\hline
\end{tabular}

The properties of soils from the mechanical automobile shops had been altered by contamination with petroleum hydrocarbon fuels. With the exception of particle size distribution, $\mathrm{pH}$, temperature and nitrogen, all other properties of soils from the mechanical automobile garages were significantly different from those of the control sites. The contamination will make the soil toxic and significantly alter all the soil properties, the carbon: nitrogen ratio and consequently affect bacteria diversity.

Acknowledgement: Supports for this work were provided by World Bank African Centre of Excellence in Oilfield Chemicals (ACE-CEFOR), University of Port Harcourt, Port Harcourt, Nigeria and University of Cape Coast. The authors wish to thank Professor John Kwesi Bentum and Professor David Kofi Essumang of the School of Physical Sciences, University of Cape Coast, Ghana, as well as Thomas Robin Davis of the Department of Fisheries and Aquatic Sciences, University of Cape Coast, Ghana for their advise and technical support.

\section{REFERENCE}

Abidemi, OO (2011). Levels of $\mathrm{Pb}, \mathrm{Fe}, \mathrm{Cd}$, and $\mathrm{Co}$ in soils of automobile workshop in Osun State, Nigeria. J. of Appl. Sci. Environ. Manage. 15(2) 279-282.

Abosede, EE (2013). Effect of Crude Oil Pollution on Some Soil Physical Properties. IOSR J. of Agric. \& Vet. Sc. 6(3): 14 - 17.

Ahmad, I; Rehan, M; Balkhyour, MA; Abbas, M; Basahi, JM; Almeelbi, T; Ismail, IMI I (2016).
Review of environmental pollution and health risks at motor vehicle repair workshops: challenges and perspectives for Saudi Arabia. Int. J. Agric. Environ. Res. 2 (1): 1-23.

Alzoubi, MM; Gaibore, M (2012). The effect of phosphate solubilizing bacteria and organic fertilization on availability of Syrian rock phosphate and an increase of triple superphosphate efficiency. World J. Agric. Sci. 8(5): 473-478.

ASTM D 6913/D6913M-17: Standard test methods for particle size distribution (gradation) of soils using sieve analysis.

Balks, MR; Paetzold, RF; Kimble, JM; Aislabie, J; Campell, IB (2002). Effects of hydrocarbon spills on the temperature and moisture regimes of Cryosols in the Ross Sea Region. Antarctic Science 14(04): 319-326.

Bayat, Z; Hassanshahian M; Hesni, MA (2015) Enrichment and isolation of crude oil degrading bacteria from some mussels collected from the Persian Gulf. Mar. Pollut. Bull. 101(1):88-91.

Bennett, PC; Siegel, DE; Baedecker, MF; Hult, MF (1993). Crude oil in a shallow sand and gravel aquifer - 1. Hydrology and inorganic geochemistry. Applied Geochemistry. 8(6):529549

Demie, G (2015). Analyzing soil contamination status in garage and auto mechanical workshops of Shashemane City: Implication for hazardous 
waste management. Environ. Syst. Res. 4: 15. https://doi.org/101186/s40068-015-0040

DIN 19684-3 20008-08. Methods of soil investigations for agricultural water engineering chemical laboratory test - Part 3: Determination of the loss on ignition and the residue of soil after ignition.

Dindar, E; Sagban, FOT; Baskaya, HS (2015). Variations of soil enzyme activities in petroleumhydrocarbon contaminated soil. International Biodeterioration \& Biodegradation. 105: 268275

Ezeigbo, OR; Ukpabi, CF; Abel-Anyebe, O; OkikeOsisiogu, FU; Ike-Amadi, CA; Agomoh, NG (2013). Physicochemical properties of soil contaminated with refined petroleum oil in Eluama Community, Abia State, Nigeria. International Journal of Scientific Research and Management (IJSRM). 1(8) 405-413.

Faoro, H; Alves, AC; Souza, EM; Rigo, LU; Cruz, LM; Al-Janabi, SM; Monteiro, RA; Baura, VA; Pedrosa, FO (2010). Influence of soil characteristics on the diversity of bacteria in the Southern Brazilian Atlantic Forest. Appl. Environ. Microbiol. 76 (14): 4744-9.

Ghana Statistical Service (2010). 2010 Population and Housing Census

Gong, Z; Li, P; Wilke, BM; Alef, K (2008). Effect of vegetable oil residue after soil extraction on physicochemical properties of sandy soil and plant growth. Journal of Environmental Sciences. 20 (12): 1458-1462.

Guo, CL; Zhao, YH; Wang, YF (2016). Research on repairing oil pollution by hydrocarbon degradation microbes. Applied Chemical Industry, 45 (6): 1156 (in Chinese)

He, LJ; Wei, DZ; Zhang, WQ (1999). Research of microbial treatment of petroleum contaminated soil. Advances in Environmental Science. 7(3): 110-111 (in Chinese).

ISO 11465 (1993) Soil Quality - Determination of dry matter and water content on a mass basis (gravimetric method).

ISO 10693 (1995) Soil Quality - Determination of carbon content (volumetric method)
ISO 10390 (2005) Soil Quality - Determination of pH.

ISO DIS 11272 (2017) Soil Quality - Determination of dry bulk density.

Jia, J; Liu, Y; Li, G (2009). Contamination characteristics and its relationship with physicochemical properties of oil polluted soils in oilfields of China. Journal of the Chemical Industry and Engineering Society of China. 60 (3): 726-732

Khamehchiyan, M; Hossein, CA. and Tajik, M (2007) Effects of crude oil and oil contamination on geotechnical properties of clayey and sandy soils. Engineering Geology. 89 (3): 220-229. Doi: 10.1016/j.enggeo.2006.10.009

Kisic, I; Mesic, S; Basic, F; Brkic, V; Mesic, M; Durn, G; Zgorelec, Z; and Bertovic, L (2009). The effect of drilling fluids and crude oil on some chemical characteristics of soil and crops. Geoderma 149 (3-4): 209-216.

doi:101016/j.geoderma.2008.11.041

Kpakpavi, M (2015). Used oil storage and disposal practices in automobile repair garages in Ghana. International Journal of Science, Technology and Society. 3 (4): 191-201. doi: $10.11648 /$ j.ijsts.20150304.23

Kumar, SSR; Rao, KVB (2012). Biological nitrogen fixation: A review. Int. J. Adv. Lif. Sci. 1: 1-9.

Leahy, JG; Colwell, RR (1990). Microbial degradation of hydrocarbons in the environment. Microbiol. Rev. 54(3): 305-315.

Liao, JQ; Wang, J; Huang, Y (2015). Bacterial community features are shaped by geographic location, physicochemical properties, and oil contamination of soil in the main oil fields of China. Microb. Ecol. 70: 380-389.

Lin, TC; Pan, PT; Cheng, SS (2010). Ex-situ bioremediation of oil-contaminated soil. Journal of Hazardous Materials 176 (1-3): 27-34.

Marais, JP; Therion, JJ; Mackie, RI; Kistner, A (1998). Effect of nitrate and its reduction products on the growth and activity of the rumen microbial populations. British Journal of Nutrition. 59 (2): 301-313. 
Mussa, SAB; Elferjani, HS; Haroun, FA; Abdelnabi, FF; (2009). Determination of available nitrate, phosphate, and sulfate in soil samples. Int. J. Pharm Tech Res. 1(3): 598-604.

Nesme, T; Colomb, B; Hinsinger, P; Watson, CA (2014) Soil phosphorus management in organic cropping systems: From current practices to avenues for more efficient use of resources. In: Bellon, S; Penvern, S (eds). Organic farming, prototype for sustainable agricultures. Springer, Netherlands 23-45.

Ndimele, PE; Saba, AO; Ojo, DO; Ndimele, CC; Anetekhai, MA; Erondu, ES (2018). Remediation of crude oil spillage. In: The political ecology of oil and gas activities in the Nigerian aquatic ecosystem. Ed; Academic Press, London, UK: 369-384.

Nimmo, JR (2004). Porosity and pore size distribution. Encyclopedia of soils in the environment 3: 295303.

Nkwoada, AU; Alisa, CO; Amakom, CM (2018). Pollution in Nigerian Auto-Mechanic Villages: A Review. Environmental Science, Toxicology and Food Technology. 12: (7) 43-54

Nwaogu, LA; Onyeze, GOC (2010). Environmental impact of gas flaring on Ebocha-Egbema, Niger Delta. Nigeria Journal of Biochemistry and Molecular biology, 25 (1): 25-30

Oluwajiose, O; Akinsete, S; Ana, G; Omishakin, A (2015). Soil contamination by refined crude oil using Lumbricus terrestris as toxicity indicator at a petroleum product depot, Ibadan, Nigeria. Current Journal of Applied Science and Technology 9(1): 37-46.

Pathak, H; Bhatnagar, K; Jaroli, DP (2011). Physicochemical properties of petroleum polluted soil collected from transport Najar (Jaipur). Indian Journal of Fundamental and Applied Life Sciences. 1(3) 84-89.

Patil, PB; and Shivare, TA (2004). Sustainable rural development and Environmental Protection. Kurukshetra 53 (1): 28.

Parlak, M; Parlak, AÖ (2011). Effect of soil compaction on root growth and nutrient uptake of forage crops. Journal of Food, Agriculture \& Environment. 9 (3): 275-278
Roy, JL; McGill, WB; Rawluk, MD (1999). Petroleum residues as water-repellent substance in weathered nonwettable oil-contaminated soils. Can. J. Soil Sci. 79 (2): 367-380.

Schnecker, J; Wild, B; Hofhans, F; Eloy Alves, RJ; Barta, J; Capek, P; Fuchslueger, L; Genstsch, N; Gittel, A; Guggenberger, G; Hofer, A; Kienzl, S; Knoltsch, A; Lashchinsiy, N; Mikutta, R; Santrůčková, H; Shibistova, O; Takriti, M; Urich, T; Weltin, G; Richter, A (2014). Effects of soil organic matter properties and microbial community composition on enzyme activities in cryoturbated arctic soils. PLoS One 9(4): doi: 10.1371/journal.pone.0094076

Smit, E; Leeflang, P; Gommans, S; van den Broek, J; van Mil, S; Wernars, K (2001). Diversity and seasonal fluctuations of the dominant members of the bacterial soil community in a wheat field as determined by cultivation and molecular methods. Appl. Environ. Microbiol. 67 (5): 2284-2291.

Stanley, HO; Offorbuike, OM; Stanley, CN (2017). Bioremediation of crude oil contaminated soil using Pleurotus pulmonarius, a white rot fungus. IOSR Journal of Environmental Science, Toxicology and Food Technology. 11(4): 122128.

Udeh, NU; Nwaogazie, IL; Momoh, Y (2013). Bioremediation of crude oil contaminated soil using water hyacinth (Eichhornia crassipes) Pelagia Research Library Adv. Appl. Sci. Res. 4 (2): 362369

Ujowundu, CO; Kalu, FN; Nwaoguikpe, RN; Kalu, OI; Ihejirika, CE; Nwosunjoku, EC; Okechukwu, RI (2011). Biochemical and physical characterization of diesel petroleumcontaminated soil in southeastern Nigeria. Res. J. Chem. Sci. 1 (8): 57-62.

Useh, MU; Etuk-Udo, GA; and Dauda, MS (2015). Evaluating the physicochemical properties and heavy metals in soils of municipal wastes dumpsites at Kubwa, Abuja, Nigeria. Journal of Chemistry and Chemical Sciences, 5: 654-662.

Walker, JD; Petrakis, L; Colwell, RR (1976). Comparison of the biodegradability of crude oils. Can. J. Microbiol.. 22(4):598 -602.

Wang, X; Feng, J; Wang, J (2009). Petroleum hydrocarbon contamination and impact on soil 
characteristics from oilfield Momoge wetland.

Huan Jing Ke Xue 30 (8): 2394 - 2401

Wang, Y; Feng, J; Lin, Q; Lyu, X; Wang, X; Wang, G (2013). Effects of crude oil contamination on soil physical and chemical properties in Momoge Wetland of China. Chin. Geogra. Sci. 23(6): 708 715. doi: 10.1007/s11769-013-0641-6

Wang, B (2014). Mechanism of growth and physiological response of three arbor species to oil contamination. Shaanxi: Northwest A\&F University.

WHO (2014). 7 million premature deaths annually linked to air pollution.

Wilke, BM (2005). Determination of chemical and physical properties - Soil dry mass and water content. In: Margesin, R; Schinner, F (Eds.) Manual for soil analysis - Monitoring and assessing soil bioremediation. Springer, Germany. $52-57$.
Yawson, DO; Kwakye, PK; Armah, FA; Frimpong, KA (2011). The dynamics of potassium (k) in a representative soil series of Ghana. ARPN $J$. Agric. Biol. Sci. 6(1):1990-6145.

Youssef, NH; Elshahed, MS (2008). Diversity rankings among bacterial lineages in soil. ISME J. 3 (3): 305-313.

Zhang, MM; Wang, N; Hu, Y; Sun, G. (2018). Changes in soil physicochemical properties and soil bacterial community in mulberry (Morus alba L.) / alfalfa (Medicago sativa L.) intercropping system. Microbiology Open 7(2): 1-11. 